Vol. 2, nº 1 | 1998

Varia

\title{
Prosecution, Society and Politics : the Penalization of Economic Collaboration in Belgium After The Second World War
}

Dirk Luyten

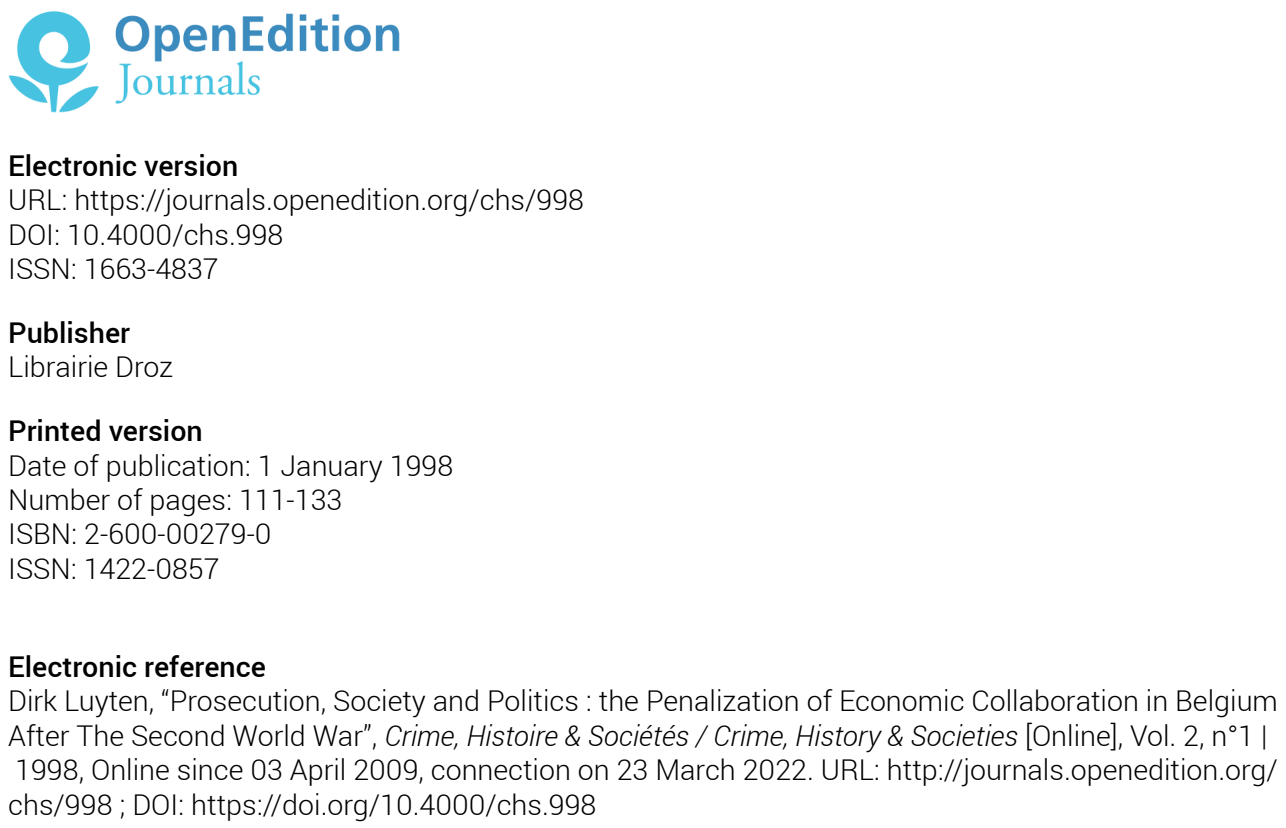




\title{
Prosecution, Society and Politics: The Penalization of Economic Collaboration in Belgium Affer The Second World War
}

\author{
Dirk Luyten ${ }^{1}$
}

$T^{n}$ this article the perception of economic collaboration by Belgian population

lafter the Second World War and its consequences for the policy of the prosecution service are examined. There was no general dissatisfaction on the way Belgian entrepreneurs behaved during the war. Only those who worked exclusively for the needs of the German army or mistreated the workers were attacked. Another target of public discontent were small entrepreneurs as grocers or innkeepers who were accused of black market activities. This attitude can be explained by the fact that workers feared deportation to Germany and therefore accepted that industry was kept in activity. This was in line with the policy of the main holding companies. As a consequence, the prosecution service found not much support for its ambitious policy that was also directed against big firms. On the other hand, the reactions of the population made clear that public opinion would not accept that economic collaboration in general remained without punishment. Therefore a prompt trial and severe sanctions against entrepreneurs who had done business with the enemy were a priority for the Chief Military Prosecutor Ganshof, van der Meersch.

Cet article analyse la perception de la collaboration économique dans la population belge après la Deuxième Guerre mondiale et ses conséquences sur la politique du ministère public. Il n'existait pas de mécontentement général au sujet de la conduite des entrepreneurs belges durant la guerre. Seuls furent pris à partie ceux qui travaillaient exclusivement au service de l'armée allemande, ou qui maltraitaient les travailleurs, ou encore de petits entrepreneurs, épiciers, cafetiers, soupçonnés de marché noir. Cette attitude consistant à accepter la poursuite de l'activité industrielle s'explique par la crainte des ouvriers d'être déportés en Allemagne et était du reste conforme à la politique des holdings. Il en résulta que le ministère public ne trouva pas beaucoup de soutien à son ambitieuse politique qui visait également les grandes entreprises. D'un autre côté, les réactions de la population mon-

1 Dirk Luyten, born in 1963, is postdoctoral fellow of the Fund for Scientific Research Flanders (Belgium). He works at the Law Department of the Vrije Universiteit Brussel. His current research is on the penalization of economic collaboration after World War I and World II in Belgium in comparative European perspective. His publications include books and articles on corporatism, the financial crisis of 1848 in Belgium, the history of the Belgian system of collective bargaining and prosecution of economic collaboration after the Second World War. Recent titles: Burgers boven elke verdenking? Vervolging van economische collaboratie in België na de Tweede Wereldoorlog. Brussel, VUBPRESS, 1996 and Ideologisch debat en politieke strijd over het corporatisme tijdens het interbellum in België. Brussel, Royal Academy, 1996. @ Librairie Droz 
traient que l'opinion publique n'accepterait pas l'impunité de l'ensemble de la collaboration économique. C'est pourquoi le prompt procès et la punition sévère des entrepreneurs ayant fait affaire avec l'ennemi étaient une priorité pour l'auditeurgénéral Ganshof, van der Meersch.

There is little research on the prosecution and punishment of acts of economic collaboration after the Second World War. And the few studies that have dealt with it tend to take a rather idealistic, and sometimes moralizing approach. The implicit premise of their analysis is that the judiciary should be «impartial » and must not be influenced by political pressure or by what is referred to as «public opinion ${ }^{2}$.

This approach, which is no longer favoured to the same extent in modern criminal law theory, is not adequate to explain the actions taken by the courts ${ }^{3}$. It may even be anachronistic inasmuch as the judicial policy immediately after the war is examined and tested by means of present-day legal standards, which are highly institutional and ideal-typical (an independent judiciary, which only judges on legal grounds).

It is this approach which dominates Belgian historiography on the so-called «repression" (the clampdown on former collaborators) and results in a clearly negative assessment of the way collaboration was dealt with. The prosecution and punishment of acts of economic collaboration is a crucial element in the criticism of the way the judiciary operated, and which did not meet the criteria of the proper dispensation of justice. The latter implies equality before the law, which is reflected in the equal punishment of similar types of crimes in the various judicial districts and an equal treatment of the various kinds of collaboration ${ }^{4}$.

It is precisely in this area that the punishment of economic collaboration went wrong. This form of collaboration with the enemy was prosecuted far less than political and military collaboration, whereby the big economic collaborators, i.e. large industrial concerns, got off scot-free. This result has been ascribed to the existence of a tacit agreement between the judiciary and the government to pass over industrialists who had done business with the enemy, as they played a crucial role in the reconstruction. Furthermore, as the government was involved in the construction of a social system which relied on all classes working together, it did not wish to antagonize the industrialists unnecessarily. This largely contributed to the general feeling at the time that there was a biased sense of justice, which undermined the legitimacy of the repression.

It is difficult to verify these theories as there has been too little investigation of the primary sources. Moreover, the basic premises of this approach are flawed; it does not sufficiently take into account the relation between the judiciary and the social environment. Too little attention has been paid to the social and political views and mentalities of the judges, and the political force field within which the courts had to operate is not adequately examined. The most important criticism of this approach, however, involves the evaluation of the legitimacy of the actions taken by the courts. This can only be assessed in relation to the overall context of the period and based on an analysis of the population's views and responses, and not $a$ posteriori by applying current standards. In this article, it is primarily the latter aspect that we will deal with. The central question in this respect is how the popula-

\footnotetext{
2 Martinage (1995); Rochebrune, Hazera (1995).

3 'T. Hart (1994).

4 In the first place Huyse, Dhondt (1993) and Huyse, Hoflack (1995).
} 
tion looked at the repression of economic collaboration, their expectations and the extent to which this influenced the judiciary. Among hisorians there is increasing emphasis on the interference between the way in which public opinion perceives reality and the political decision-making processes ${ }^{5}$. The same question may be put with regard to the policy of the Crown Prosecution Service, especially in the period of crisis of authority after the Second World War.

We will examine the policy of the Chief Military Prosecutor (auditeur-generaal, auditeur-général) Walter-Jean Ganshof van der Meersch. This legist headed the military prosecution departments, laid down the prosecution policy and supervised its execution. He was without any doubt the central figure in the postwar repression period. In addition, Ganshof van der Meersch was High Commissioner for the Security of the Territory (Hoog Commissaris voor's Lands Veiligheid; Haut Commissaire à la Sécurité de l'État), an institution set up by the Belgian government in exile in London in order to ensure a smooth liberation of the country, with law and order being a priority.

The fact that he wore several hats is already quite remarkable. The High Commissioner's Office monitored public opinion, and its reports allow us to reconstruct the ideas and sentiments among the population at the time. This constitutes the bulk of the paper. However, in order adequately to interpret these data it is necessary to examine the judicial apparatus during the repression. The following paragraph deals with the role played by the High Commissioner's Office for the Security of the Territory and its relationship with the military tribunals.

The provinces of Belgium

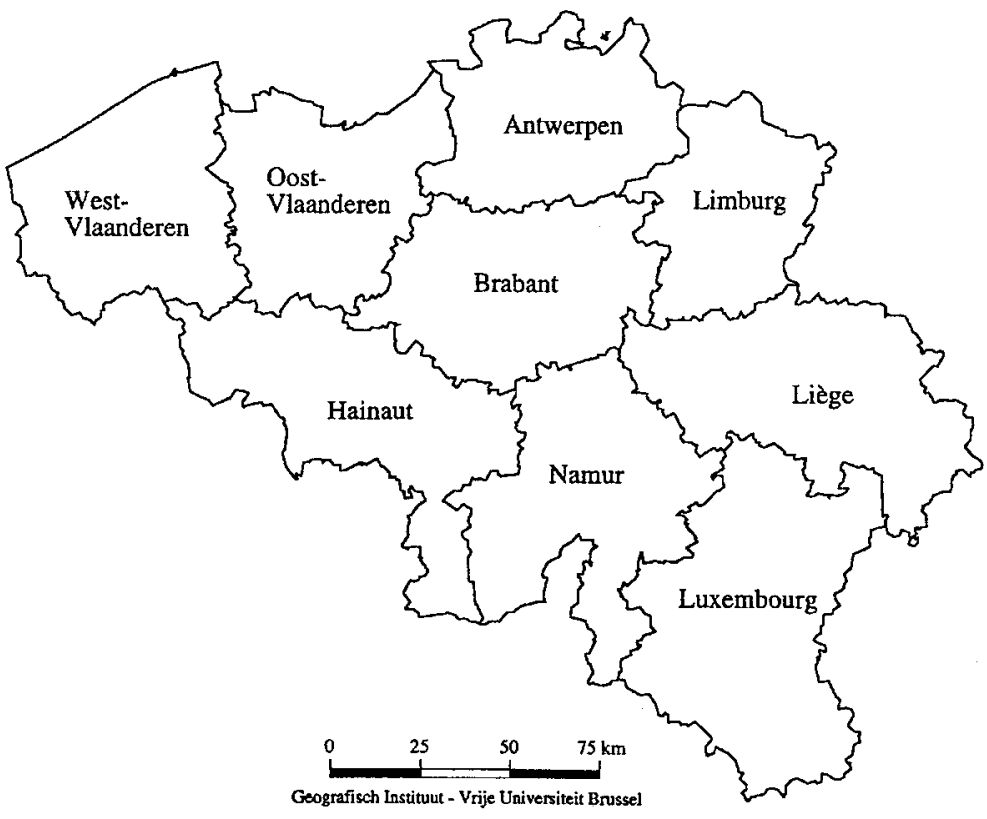




\section{THE ORGANIZATION OF THE REPRESSION}

The prosecution and punishment of crimes committed against the external security of the state was entrusted to the military judiciary, which consisted of courts martial (krijgsraden, conseils de guerre) and the Court of Military Appeals (Krijgshof; Cour militaire), which were part of the ordinary judiciary. Any proposals to directly involve the resistance in the repression met with Ganshof's veto. The courts martial and Court of Military Appeals were composed of a civilian magistrate and lay judges, who were officers or reserve officers. With a view to processing the acts of collaboration, the number of civilian magistrates was increased. As the number of courts martial and courts of military appeals rose dramatically, it became necessary to call on more reserve officers. The combination of these two factors resulted in a weakening of the strictly military character of these courts.

The Crown Prosecution Service was controlled by the military prosecutors (krijgsauditeur; auditeur militaire) and their assistants (substituut, substitut). Here, too, the staff was increased in order to try collaboration more effectively. At the level of the Court of Military Appeals, the Crown Prosecution Service was represented by the chief military public prosecutor, his assistants (substituut, substitut) and court of appeals public prosecutors (advocaat-generaal, avocat-général). One of them was charged specifically with dealing with economic collaboration. Contrary to non-military criminal law, the public prosecution departments were headed by one single person, i.e. the Chief Military Prosecutor, whose jurisdiction extended across the country, rather than being limited to a number of judicial districts as is the case for a Chief Prosecutor (procureur-generaal, procureur-général) ${ }^{6}$.

Ganshof was both Chief Military Prosecutor and High Commissioner for the Security of the Territory, the body which was founded on 29 July 1943 . The appointment of Ganshof, who had been the Chief Military Prosecutor since 1940, followed only a few days later. The duty of the High Commissioner was to ensure the security of the state and the maintenance of law and order. In addition, the High Commissioner had to keep the ministers abreast of the situation in their areas of competence, and possibly recommend certain measures. The High Commissioner was also responsible for the coordination of the security and action services and was consequently well informed about the situation and popular feeling in occupied territories.

The High Commissioner's main concern, to which all other things were in fact subordinate, was the maintaining of law and order after the liberation. This task had a political aim, since Belgium was confronted with several political problems after the liberation that made restoration of the prewar political system and the legitimacy of the state difficult. The London government was not very popular and had to compete with the resistance movements, which aspired to political power. King and government had been in conflict since May 1940. The position of the King was a quasi permanent source of confrontation that opposed left and right. The Communist Party had participated actively in the struggle against the Germans and had as a consequence gained much sympathy. The Party created a network of organizations including a trade union but aimed at political participation following an adapted version of the Popular Front strategy. The Party became a partner in the government

- Gilissen (undated, p. 11-17). For more details on the organization of the military courts and their activities: Huyse, Dhondt (1993) and Gilissen (1951). 
coalition but was nevertheless considered to be a threat by the traditional political powers. In this political context, the London government aimed at a quick restoration of the authority of the state. Ganshof had a key role to play in this process as High Commissioner as well as Chief Military Prosecutor?. A priority in this restoration process was the punishment of collaboration, which should be dealt with as quickly as possible. To this end, the High Commissioner also contributed to a number of statutory orders appurtenant to the organization of courts martial, the procedure and the withdrawal of certain rights of those convicted of collaboration. Although the High Commissioner was involved in other legislative actions, the repression constituted the lion's share of his brief. In the implementation phase, the maintenance of law and order and the repression that went along with it played a prominent role ${ }^{8}$.

The High Commissioner's Office was involved in the repression in two instances, or, to be more precise, in two aspects of the same issue. First of all, the officers were faced with the population's reactions against the collaborators. And secondly, the High Commissioner's Office played a central role in the internment of alleged collaborators.

As had been the case after the First World War, the judicial, police and administrative powers that be were given the authority to intern Germans and Belgians who were suspected of having collaborated with the enemy and thus posed a threat to public safety. The category of 'suspect' Belgians included those who had borne arms and/or worn the enemy's uniform, those who had worked in German administrative services, and any other persons whose behaviour during the occupation had been such that they had caused a scandal or could cause a disturbance of public order in that their release would invite reprisals. One observer noted that: «Here concern for their safety is merged with concern for the preservation of public order. ${ }^{9}$ The officers of the High Commissioner's Office had to communicate guidelines for the internments to the competent authorities, and organize the internments and the centres to such an extent as was necessary to maintain public order. Furthermore, the High Commissioner, as Ganshof himself pointed out, had been closely involved in the drawing up of guidelines pertaining to the internments ${ }^{10}$. The circular containing these guidelines emphasises the relationship between maintaining public order and the repression. One contemporary analysed the situation as follows. Not all military prosecution departments were able to start their operations immediately after the liberation. In the period between the liberation and the first tribunals, the civilian prosecution departments would have to act against the collaborators. These were, however, «...too accustomed to respecting individual liberties to impose on traitors the preventive detention that public opinion was clamouring for ${ }^{11}$. This view was also shared by Ganshof.

Looking back on his activities as High Commissioner, he called the popular reactions against the collaborators one of the most important sources of unrest. In his

7 There is an abundant literature on post-war Belgium. We limit ourselves to two basic titles in French: Gotovitch (1992), Gérard-Libois, Gotovitch (1991).

8 Rapport... (S.d., p. 11-29).

9 "Le souci de leur sécurité se confond ici avec celui du maintien de l'ordre», Cassart (1944, p. 9-19).

10 Rapport... (S.d., p. 9-19).

11 «Trop habitués au respect des libertés individuelles pour prendre à l'égard des traîtres les mesures de détention préventive, que l'opinion publique exigeait avec fracas», Cassart $(1944$, p. 21). 
view, they were entirely to be expected: «There was nothing surprising about such reactions: the population, wich had suffered at the hands of the enemy and their collaborators, had a passionate desire to see those who had betrayed their country or benefited from enemy occupation punished, although they were not always aware of the enormous difficulties entailed in organizing the problem of repression and pursuing an ideal of justice in accordance with legal process and the law. ${ }^{12}$

There were two peaks in the reactions against collaborators: immediately after the liberation and in May 1945, when the return of prisoners of war stirred up violent emotions among the population. The High Commissioner's Office informed the government of these reactions and requested measures that be taken, while attempting to ease the tension ${ }^{13}$.

The fact that the Chief Military Prosecutor and the High Commissioner for the Security of the Territory, who was responsible for the maintenance of law and order, were one and the same person clearly reveals the close relationship between the repression and the reactions on the part the population. In other words, it shows the need to legitimize the punishment of collaboration to the people. This symbiosis also manifested itself in logistical details. The High Commissioner's officers were instructed to establish their offices in the immediate vicinity of the military tribunals ${ }^{14}$.

The result of the combination of the two positions was that Ganshof was kept directly informed of the development of public opinion and of any bursts of outrage against the collaborators on the part of the population. The High Commissioner's officers, who operated on a provincial level, regularly reported on the general opinion in their areas. This information was complemented by reports from the national security service and from the state police (rijkswacht/ gendarmerie). The latter moreover compiled detailed reports of attacks on collaborators and of social conflicts. These sources allow a reconstruction of the population's perception of economic collaborators.

\section{PUBLIC OPINION AND ECONOMIC COLLABORATION}

\section{A. The nature of the sources}

The information about the way economic collaboration was perceived by the population, and which is contained in the reports in the archives of the High Commissioner's Office, can be divided into four levels.

The first level is that of physical reactions against collaborators. These involved acts of violence against alleged collaborators, attacks on their houses, the pillaging of their possessions, the burning of furniture, smashing of windows, the painting of swastikas, etc. These are known directly through the reports, by the gendarmerie in particular.

12 «Elles n'avaient rien de surprenant: la population, qui avait souffert du fait de l'ennemi et de ses collaborateurs, désirait passionnément voir punir ceux qui avaient trahi leur pays ou tiré profit de l'occupation ennemie, sans toujours se rendre compte des énormes difficultés que présentaient l'organisation du problème de la répression et la «poursuite d'un idéal de justice» conformément au droit et à la loi.»

13 Rapport... (S.d., p. 30).

14 Ibidem (p. 105). 
The second level of perception revolves around the population's views of economic collaboration and the prosecution of it. This becomes clear indirectly from the reports by the national security service (staatsveiligheid; sûreté de l'État) on the development of public opinion.

The third level is of an organizational nature. Political parties and resistance organizations held rallies and distributed posters and pamphlets in an attempt to channel and politicize the displeasure of the population. This does not directly reflect the way public opinion perceived economic collaboration, but it does provide some indication of the specific foci, which, or so it was assumed by these organizations, would strike a chord with the population.

The last level consisted of social conflicts and trade-union activities. These inform us on the way workers within a particular company judged their employer's position during the war.

This material is supplemented by reports and correspondence containing more details on certain demonstrations or events. They provide details on the sociological backgrounds of the demonstrators or on their political intentions. In this respect, it is important to consider the attacks against the collaborators. Some historians maintain that demonstrations against collaborators were entirely unspontaneous and incited and coordinated by resistance organizations, particularly the communists, who thus attempted to destabilize the state ${ }^{15}$. This thesis is not substantiated by the archives of the High Commissioner's Office. In his final report, Ganshof remarked that, on the whole, the reactions against the collaborators arose spontaneously. It was only after some time that they were provoked or organized ${ }^{16}$. According to Ganshof, the exploitation for political purposes or for personal revenge of what he called «the population's legitimate sense of outrage " should be situated around the end of May, or early June $1945^{17}$. The comments on the reports allowed the cancelling out of these types of attacks, and they are not included in the counts.

\section{B. Protests against collaborators}

The attacks against collaborators reached a peak in the spring of 1945, when the political prisoners returned from Germany. At that moment, more and more trials of economic collaboration were held. In March 1945, 26 economic collaborators had been sentenced. By the 1 st June 1945 the number was $103^{18}$. Previously, few acts of violence against collaborators had been reported. However, there was a great deal of disenchantment among the population with the organization of internment camps and the release policy that was conducted there. In theory, decisions on this were not taken by the military judges, but by the Minister of Justice; in practice, however, the decision-making powers lay with consultative commissions which advised the minister. These consisted of a magistrate and solicitors ${ }^{19}$. The population as well as certain police forces complained that prominent Germanophiles and economic col-

15 Pauwels (1994).

16 Rapport... (S.d., p. 30).

17 Ganshof to the Prime Minister, 26.V.1945 and 2.VI.1945, SOMA (Studie-en Onderzoekscentrum Oorlog en Hedendaagse Maatschappij / Centre d'Études Guerres et Sociétés contemporaines), Hoog Commissariaat voor's Lands Veiligheid, 1311.

18 Report of Ganshof for the Ministre of Justice 1st June 1945, SOMA.

19 Cassart (1944, p. 35). 
laborators were released more quickly and more easily by the commissions ${ }^{20}$. The internees themselves were not happy either with the policies implemented by the commissions. In the St. Kruis camp, near Brugge, a revolt broke out among the internees because a prominent economic collaborator was set free ${ }^{21}$.

Not only were economic collaborators released more quickly and more easily, they also enjoyed various privileges. This was most visible in the distribution of parcels sent by relatives of certain rich internees. In December 1944, the national gendarmerie commander recommended that the distribution of parcels should in fact be forbidden. It favoured the rich, and the goods could be bought with ill-gotten gains resulting from, for instance, black-marketing during the war. It was this which shocked the population ${ }^{22}$.

Disenchantment with judicial action itself was quite limited. In the West Flanders town of Roeselare, there was some dissatisfaction about the fact that some unnamed economic collaborators were left alone ${ }^{23}$. In the Hainaut town of Tournai, a liqueur trader, who was suspected of black-marketeering during the occupation, was the victim of an assault ${ }^{24}$. However, in the first six months after the liberation there was no general sweeping protest against the way the judiciary dealt with economic collaboration. There was, however, widespread opposition to the social inequalities in the internment camps, both in terms of material advantages and early releases. By the spring of 1945 , the situation had changed dramatically.

With varying degrees of intensity, collaborators all over the country suffered the wrath of the population. The table below (p. 125) lists all types of attacks against collaborators of all types, for each province ${ }^{25}$.

The table reveals that the release of internees remained a bone of contention, albeit with different degrees of intensity in the various provinces. There was particular disenchantment in the provinces of Hainaut, Oost-and West-Vlaanderen. Most striking is the great difference in the number of attacks between the provinces. The animosity against collaborators was the greatest in Oost-and West-Vlaanderen and Hainaut, whereas the number of actions against collaborators in Namur and Luxembourg was negligible. There was not always a direct connection with the industrial character of the provinces, as the low score in the industrial province Liège shows.

20 Report state security police Mechelen 5.I.1945, SOMA, Hoog Commissariaat voor's Lands Veiligheid, 1252; Hainaut 3.II.1945, ibidem, 1279; National commander gendarmerie to the commander for the province of Limburg 13.XII.1944, ibidem, 1292; Ganshof to the Minister of Justice 7.I.1945, ibidem, 1211.

21 National commander of the gendarmerie to the Military Prosecutor in Brugge 14.XII.1944, SOMA, Hoog Commissariaat, 1211. For the location of the towns see the map of Belgium.

22 National commander of the gendarmerie to the High Commissioner for National Security 16.XII.1944, SOMA, Hoog Commissariaat, 1211 and State security police to assistant Chief Military Prosecutor Landrien 27.I.1945, ibidem, 1247.

23 Report state security police Roeselare 21.XII.1944, SOMA, Hoog Commissariaat, 1271.

24 Report state security police Hainaut 3.II.1945, SOMA, Hoog Commissariaat, 1279.

25 Table based on reports of state security police, gendarmerie and officers of the High Commissionership for National Security and the local police in SOMA, Hoog Commissariaat, 1303-1306, 1307$1309,1315-1316,1320-1321,1325$. The number of 'unknown' cases is rather high, but we can assume that not many industrialists are included since they were well known to the police. The validity of our conclusions concerning economic collaboration is not put into question. 
Table 1: Attacks against collaborators

\begin{tabular}{|l|c|c|c|l|}
\hline & \multicolumn{3}{|c|}{ Number of attacks against: } & \\
\hline Province & $\begin{array}{l}\text { Alleged } \\
\text { collaborators }\end{array}$ & $\begin{array}{c}\text { Released } \\
\text { internees }\end{array}$ & $\begin{array}{c}\text { Type of victim } \\
\text { unknown }\end{array}$ & Period \\
Luxembourg & 2 & & & \\
Namur & 7 & 0 & 0 & V 1945 \\
Liege & 12 & 2 & 3 & V-VIII 1945 \\
Antwerpen & 22 & 0 & 3 & IV-VIII 1945 \\
Brabant & 23 & 0 & 0 & V 1945 \\
Limburg & 151 & 19 & 48 & III-V 1945 \\
West-Vlaanderen & 296 & 15 & 170 & IIII/V1945 \\
Hainaut & 393 & 56 & 83 & XII 19454/III-V 1945 \\
Oost-Vlaanderen & 415 & 18 & 214 & II-VII 1945 \\
Total & 1321 & 110 & 524 & \\
\hline
\end{tabular}

Table 2: Percentage of workers employed in industry $(1937)^{27}$

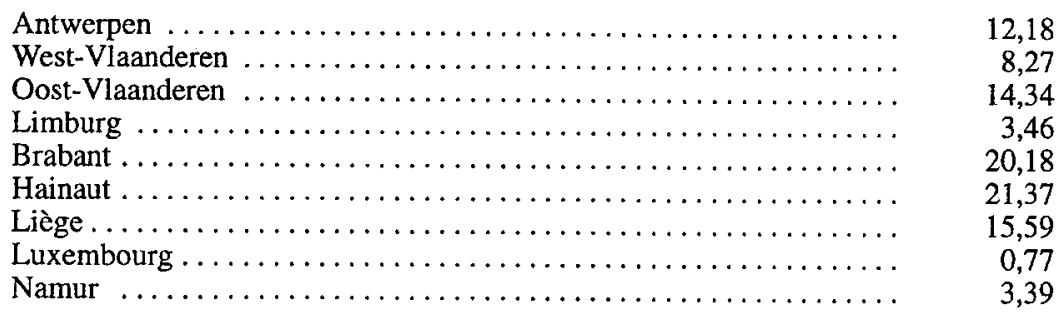

Although the period during which the attacks took place also differed, there was no connection between the number of attacks and the time frame in which they occurred.

Local phenomena such as specific events during the occupation, political power balance, the policy of the consultative commissions and the military prosecutors all played a role in the attacks. The military prosecutor in Charleroi ascribed the great hatred of collaborators to the severe actions by the occupier and his Belgian accomplices $^{28}$. We cannot go into this in depth as this would take us too far for the scope of this article. It is more important to know the extent to which the anger of the population turned against economic collaborators. The table below combines all attacks

26 Type of victim «unknown» means that the motivation for the attack is not clear from the police reports, or in other words, that it is not certain that an attack was directed against a collaborator. Some attacks had other backgrounds such as personal rivalries. So, the total number of attacks for which we are sure that collaboration was the reason is 797.

27 Table taken from: Veraghtert $(1979$, p. 99).

28 The Military Prosecutor in Charleroi to Chief Military Prosecutor, 7.X.1944, SOMA, Hoog Commissariaat voor's Lands Veiligheid, 1180. 
against economic collaborators in the broadest sense of the term. The crime of economic collaboration is defined in article 115 of the Penal Code, which says that any delivery of commodities of whatever kind to the enemy is punishable by death. The economic collaborators are a disparate group of traders, shopkeepers, innkeepers, industrialists and volunteers for work detail in Germany. In all these cases, we may assume that their economic activity during the war gave rise to criticism by the population, as combinations of economic and political types of collaboration were mentioned separately. This mixed category was not included in these figures.

Table 3: Share of economic collaboration in the attacks against collaborators

\begin{tabular}{|l|c|c|}
\hline Province & $\begin{array}{l}\text { Attacks against economic } \\
\text { collaborators }\end{array}$ & $\begin{array}{c}\text { Total number of } \\
\text { attacks and \% }\end{array}$ \\
\hline Luxembourg & 1 & 2 \\
Namur & 0 & 4 \\
Liège & 3 & 9 \\
Hainaut & 98 & $310(31,6 \%)$ \\
Antwerpen & 3 & 19 \\
Brabant & 1 & 23 \\
Limburg & 39 & $103(37,9 \%)$ \\
Oost-Vlaanderen & 82 & $201(40,8 \%)$ \\
West-Vlaanderen & 33 & $126(26,2 \%)$ \\
\hline
\end{tabular}

For Luxembourg, Namur, Antwerpen, Liège and Brabant, we have to limit ourselves to the absolute figures as the totals are too low to calculate percentages, making it difficult to infer many relevant conclusions from these figures. It is worth mentioning the Liège industrial area, where, despite the existence of major left-wing trade-unionist pockets, only three attacks took place against persons who had exercised an economic activity during the occupation. Furthermore, not one single industrialist fell victim to the people's wrath. The three cases concern a farmer, an innkeeper and a greengrocer. In Oost- and West-Vlaanderen, Limburg and Hainaut the share of economic collaboration was quite high. It fluctuated between $26,2 \%$ and $40,8 \%$. At first sight, this reveals a higher degree of disapproval of economic collaboration on the part of the population. However, this figure must be interpreted correctly. First of all, economic collaboration was not the main and exclusive object of criticism. This becomes evident if one takes a look at the percentages for other types of collaboration, especially political and military collaboration. In Limburg, economic collaborators constituted the dominant group. Other targeted individuals formed a heterogeneous group, with the exception of released internees, who made up $17.9 \%$ of the total. In the other provinces, the situation was entirely different. In West-Vlaanderen, the anger directed against political collaborators and municipal council members was slightly higher than that to which economic collaborators $(27.7 \%)$ were subjected. Similarly, this was also the case in Hainaut, where this group represented $30 \%$ of the total. In Oost-Vlaanderen, the dominance of political collaborators was less pronounced $(14.9 \%)$. In the same province, informers $(6.9 \%)$ and military collaborators $(5.4 \%)$ were a much-targeted group. In other words, although economic collaborators were subjected to violence, they were not the main target of the population's anger. 
The dividing line did not run between economic collaborators and other types of cooperation with the enemy, but rather between those forms of collaboration which were visible within the community and those that were not. People who had worn the enemy uniform, political collaborators and local government officials were not only visible, their activities frequently had had direct, unpleasant consequences for the population and had affected daily life. The municipal councils, for instance, played a role in the provisioning and forced employment in Germany. A more detailed analysis of the group of economic collaborators provides further confirmation of the thesis that proximity played a greater role than the type of collaboration. The data are broken down for each province in table $4^{29}$.

Table 4: Number of reactions against certain types of economic collaborators

\begin{tabular}{|l|c|l|l|l|}
\hline \multirow{2}{*}{$\begin{array}{l}\text { Types of } \\
\text { collaborator }\end{array}$} & \multicolumn{4}{|c|}{ Province } \\
\cline { 2 - 5 } & Limbourg & West-Vlaanderen & Oost-Vlaanderen & Hainaut \\
\cline { 2 - 5 } Shopkeeper & 17 & 8 & 14 & 11 \\
Tradesmen & 3 & 8 & 14 & 21 \\
Representative & - & - & - & 3 \\
Contractor & 1 & 3 & - & 2 \\
Trafficker & - & - & - & 3 \\
Industrialist & 2 & 1 & 1 & 16 \\
Voluntary worker & 1 & - & 10 & 11 \\
Farmer & - & $(33)$ & $(82)$ & - \\
(Total) & $(39)$ & & $(98)$ \\
\hline
\end{tabular}

This division puts the high number of attacks on economic collaborators into perspective. With the exception of Hainaut, the largest category is that of shopkeepers (mainly innkeepers and grocers, but also hairdressers). Again, these are individuals who were highly visible in the local community and played a central role in daily life (this is particularly true for grocers). As a result, the consequences of their actions were immediately noticeable by their local community.

The social studies on working-class families conducted by the sociologist G. Jacquemyns during the war reveal a great dislike among the working population of retailers: «They are all vagrants, hooligans who think they won't have to reckon with their customers after the war. They are dishonest and crude. $»^{30}$ They were accused of not selling enough foodstuffs to customers from lower social classes, preferring instead to sell on the black market to the rich $^{31}$. The same explanation holds true for the high number of attacks against tradesmen. In those cases where more details were given, it appears that grain and potato traders were often involved, activities connected with the provisioning of the population. Collaboration by these groups was particularly targeted by the population. In Limburg, a province with extensive mining activity, it was not the mine employers who were put up as the pro-

29 Only the most important categories are mentioned.

"Ceux-ci sont tous des vagabonds, des voyous, qui croient qu'ils ne devront plus compter avec leur clientèle après la guerre. Ils sont malhonnêtes et grossiers». 
totype of industrial collaboration by the communists, but the shopkeepers and tradesmen who were the butt of the people's wrath.

\section{INDUSTRIAL COLLABORATION}

Economic collaborators in the strictest sense of the word, such as industrialists and contractors, were not specifically targeted by the population. In West-Vlaanderen, where numerous contractors were used for the construction of German defence projects, very few attacks occurred against this group of economic collaborators. For Oost-Vlaanderen and Hainaut, the figures are less clear. Although industrialists increasingly suffered the animosity of the population, their share remained smaller than that for shopkeepers and tradesmen. As far as Hainaut is concerned, the higher proportion of industrial collaboration may be explained by the industrial character of the area, a factor which may have had the same effect in Oost-Vlaanderen. In some areas of the latter province, for instance in the town of Ronse where numerous attacks were committed against collaborators, the textile industry was a major force. More precise details on the cases of industrial collaboration show that sometimes quite specific factors triggered the anger of the population. A press campaign, the fact that a company had worked solely for the German army, or that its manager had had close ties with those responsible for the provisioning, might all be motives for an attack on an industrialist ${ }^{32}$.

In Morlanwelz (Hainaut), fifty demonstrators broke into the house of the manager of the Usines de Baume et Marpent (metal works). Although this seems at first to be a textbook example of industrial collaboration, additional information revealed that this man was targeted not because of his economic activities, but because he had informed on a few of his workers ${ }^{33}$. Consequently, there was no general pattern of protest against manufacturers who had worked for the enemy during the occupation.

Something which may appear paradoxical at first sight is the relatively high number of attacks on voluntary workers in Hainaut. This group was much hated by the population, and the confrontations were particularly violent. Their personal integrity came under threat more than that of other collaborators, and the people vented its anger on their houses and possessions. Upon their return from Germany, the voluntary workers were beaten by a mob that had gathered at the station ${ }^{34}$. The gravity with which this form of collaboration was regarded by the population becomes clear from an incident in Strépy-Bracquegnies, where voluntary workers were tarred with the same brush as the so-called «inciviques notoires» (leading political and administrative collaborators). On May 9th and 10th, a number of known collaborators were arrested by the police by order of the military prosecutor. Immediately after, a 700-strong mob brought two voluntary workers to the police station, as if they had been overlooked by the police who had earlier arrested the 'prominent collaborators ${ }^{35}$.

\footnotetext{
32 Reports in SOMA, Hoog Commissariaat, 1313.

33 Report state security police La Louvière, 11.V.1945, SOMA, Hoog Commissariaat, 1312.

34 Report state security police Zinnik/Soignies, 5-11.V.1945, SOMA, Hoog Commissariaar, 1312.

35 Report gendarmerie Houdeng- Goegnies, 11.V.1945, SOMA, Hoog Commissariaat, 1313.
} 
Voluntary workers were also heavily stigmatized in their work surroundings. At a trade-union meeting of the left-wing Mouvement Syndical Unifié in the Liègebased steelworks Cockerill, one of the speakers demanded the incarceration of the voluntary workers in a concentration camp and forced labour in a coal mine ${ }^{36}$. In some collieries, miners refused to work alongside returning voluntary workers ${ }^{37}$.

The question remains as to why workers reacted so vehemently against voluntary work. During the occupation, working conditions in the mine were relatively good. Consequently, it was said that those who went to Germany to work did not do so out of necessity or misery, but out of conviction and without any moral duress. Because of this, their actions were not forgiven ${ }^{38}$. Those who had left because of material reasons could count on their fellow workers' sympathy, whereas the others could not ${ }^{39}$. Voluntary workers who had gone to Germany because they had been attracted by better wages and working conditions went against the group norm.

Another motive which contributed to the strong sense of rejection towards voluntary labour, was what may be called a 'compensation effect'. Remaining in work during the war implied a certain degree of collusion with economic collaboration as it contributed to an activity from which the Germans derived an advantage ${ }^{40}$. And a strong reaction against the voluntary workers, which, had it been taken one step further, could, like sabotaging or slowing down production, be a way of rationalizing one's own behaviour, or of minimizing its importance.

The other side to the vehement reaction against the voluntary workers might be the fact the workers agreed with the industrialists' policy of maintaining production during the occupation, even though it benefited the enemy. This would explain the relatively low number of attacks on industrial collaborators. It is possible to support this logical conclusion with empirical evidence. During the occupation, G. Jacquemyns observed that the behaviour of employers was rarely criticized by workers and that the latter agreed to the resumption of work after the capitulation and were strongly attached to the preservation of their jobs: «The majority of workers are worried about losing their livelihood. Because 'one has to live', they want the machines to keep running; they hope they will not have to lay down their tools» ${ }^{41}$. This attitude remained fundamentally the same over the next years. The only reaction consisted of slowing down the working rhythm or of sabotage, a form of passive resistance which was also widespread among French workers ${ }^{42}$. Very few workers thought it politic to shut down production entirely. Job attachment increased after the introduction of forced labour in Germany in 1942: «nearly everyone wants to be 'busy', because the risks are slightly less for those in work than for the others. The shop, the

\footnotetext{
36. Report gendarmerie Seraing, 25.V.1945, SOMA, Hoog Commissariaat, 1621 Ganshof to the Ministers of Labour and Economic Affairs, 7.V.1945, SOMA, Hoog Commissariaat, 1653.

38 Ibidem.

39 Jacquemyns (1958, p. 26).

40 Fridenson, Robert (1992, p. 120)

41 «La majorité des travailleurs appréhendent de perdre leur gagne-pain. Ils désirent 'parce qu'il faut vivre' voir les machines continuer à tourner; ils espèrent de ne pas devoir lâcher l'outills, Jacquemyns (1958, p. 26).

42 Jacquemyns (1958, p. 27) and Fridenson, Robert (1992, p. 120).
} 
mine, the office provide shelter. If need be, one wanted to be able to show the Werbestelle a good recommendation from their employer. ${ }^{43}$

Postwar police reports reveal that attacks on industrialists were not aimed against those who had merely maintained production in their factories, but against those who had increased it. This type of protest was probably caused by indignation over the fact that the enemy was benefiting from this situation. Often, increased production also implied that workers had to work harder. The resistance against increasing production and not against the principle of maintaining economic activity also explains that it was not on the whole at the owners or managers of companies, but at the executives that popular discontent was directed. Here are some examples to clarify the above. In September 1944, the military prosecutor of Charleroi (Hainaut) reported on a social conflict in the Monceau Fontaine colliery, where the miners refused to resume work until the production manager quit. He had attempted to increase production, while the workers had slowed down and committed acts of sabotage ${ }^{44}$. Two months later, the governor of the province of Hainaut mentioned that, following a strike against a foreman who had collaborated, workers were dissatisfied with the delay in convictions of industrialists. This was not aimed at all industrialists who had kept their companies running, but only at those who had boosted their production ${ }^{45}$.

The same emphasis was voiced at rallies and demonstrations by trade unions and resistance organizations. On 14 May 1945, the Jeune Garde Socialiste (the socialist youth organization) organized a rally at which the communist, and leader of the leftwing resistance organization Independence Front (Onafhankelijkheidsfront), F. Demany and the socialist MP G. Hoyaux were the speakers. The latter, who had just returned from a German camp, demanded that measures be taken against economic collaborators, but not against all industrialists who had worked for the enemy. The industrialists: «who crawled before the 'boches' and harrassed their personnel to drive them to maximum production» had to be punished $»^{46}$. On 30 May 1945 at a rally of the socialist trade union FGTB (Fédération Générale du Travail de Belgique) in Huy, which was organized against civilian mobilization and in favour of a rise in purchasing power, attention was also paid to the repression. Again, no general measures were demanded against the industrialists who had maintained their production. Calls were made for a 'cleansing' among engineers in the metal industry ${ }^{47}$. It was not management, which drew up the general policy, but the executives, with whom the workers were in daily contact and who were charged with the implementation of the general policy, who formed the object of criticism.

43. Presque tout le monde désire être 'occupé' parce que les risques sont un peu moins grands pour ceux qui sont au travail que pour les autres. L'usine, la mine, l'atelier, le bureau, sont des refuges. Le cas échéant, on désire pouvoir exhiber à la Werbestelle une bonne attestation d'un patron.» The Werbestelle was the German office responsible for the recruitment and enrollment for Belgian workers who were forced to work in Germany; Jacquemyns (1958, p. 27).

44 The Military Prosecutor in Charleroi to the Chief Military Prosecutor, 13.IX.1944, SOMA, Hoog Commissariaat, 1071.

45 The govemor of Hainaut to the Minister of the Interior, 4.XI.1944 Rijksarchief Brugge/Archives de l'État Bruges (State Archives Bruges), Archief A. Van Acker, 492.

46 «... qui s'applatissant devant les boches, harcelaient leur personnel pour le faire produire au maximum.» Report state security police La Louvière, 14.V.1945, SOMA, Hoog Commissariaat, 1312.

47 Report gendarmerie Huy, 30.V.1945, SOMA, Hoog Commissariaat, 1621. 
Hence, there was no general protest among the population and workers against industrialists who had continued to produce, only against those who had exaggerated or had treated their workforce badly. The same picture emerges from the social conflicts at the company level. With one exception, none of the strikes revolved around the policy of the repression. The exception was a metal-construction company whose managing director had a «record of being a collaborator». Cleansing was used only to buttress social demands, such as wage increases.

In these cases, too, the social rather than the patriotic argument was used to stigmatize the employer. A case in point in this respect is a conflict led by the communist union, at the Bois-du-Luc ${ }^{48}$ colliery (Hainaut). It was aimed at a system of work measurement which would disadvantage workers, and at the repressive action taken against workers who had objected to it. The collaboration issue was linked to it, but only in its social dimension. Workers no longer wanted to be ordered around by bosses who had been 'Hitler's stooges' during the war and who threatened workers who were sabotaging or striking with being sent to Germany on work detail ${ }^{49}$.

Immediately after the liberation, the communist trade unions attempted to bring the issue of the prosecution of economic collaboration to the fore. There were calls for severe punishment by the courts and for the setting up of cleansing committees with workers as their members. Companies belonging to collaborators were supposed to be confiscated and governed by the workmen ${ }^{50}$. The Ardennes offensive was used to lend force to this demand, which, initially, did not meet with much approval. At that time, employers suspected of collaboration were also accused of having sabotaged production, as they were supposed to be hoping for a German victory ${ }^{51}$. However, despite its initial impetus, the movement quickly died out, and, during strikes in the spring of 1945, the collaboration issue no longer played a noticeable role.

Things were hardly different in the Limburg mining areas. The communist trade union attempted to gain a foothold by, among other things, playing the repression card. However, in the organization's magazine, it was not industrial collaboration as a whole which came under attack. There were calls against only one managing director of one specific mine ${ }^{52}$. And at a rally a few days later, the repression issue was completely ignored ${ }^{53}$.

The sources at the various levels show that the punishment of industrial collaboration was not a matter of principle as far as the population and the working classes were concerned. Economic activities benefiting the enemy were perceived to be a problem only if they had had a direct negative effect on the living conditions of the population and of the workers. Industrial collaborators were taken to task only if they had worked excessively for the Germans, supplied solely to the German army, or denied workers their rights. Within the category of economic collaboration as a

48 Report gendarmerie Olne, 17.VII.1945, SOMA, Hoog Commissariaat, 1621.

49 Pamphlet Comité de Lutte Syndicale (CLS), Bois-du-Luc, end october 1944, SOMA; Hoog Commissariaat, 1653.

so Report state security police La Louvière, 25.X.1944 ; Pamphlet CLS 31.X.1944, SOMA, Hoog Commissariaat, 1654

51 Unité Syndicale, L'hebdomadaire des travailleurs, Organe du bureau national des CLS et des Syndicats uniques, 27.XII.1944, IXe legaal nummer, p. 1-2, SOMA; Hoog Commissariaat, 1654.

52 Report gendarmerie Genk, 31.V.1945, SOMA, Hoog Commissariaat, 1654.

s3 Report gendarmerie Genk, 4.VI.1945, SOMA, Hoog Commissariaat, 1653. 
whole, industrialists remained a minority. Those who were closer to the population, or the result of whose activities were directly visible were far more often targeted. The public made a clear distinction between industrial collaborators, on the one hand, and war usurers (especially black marketeers), on the other. In the district of the Tongeren war tribunal, the views on the way industrial collaboration was dealt with were mostly positive. The population wondered however when the courts were going to act against the war usurers ${ }^{54}$. The animosity towards these "war usurers " lay deeper than that towards the industrial collaborators. In a pamphlet addressed to the population in November 1944, the communist union attacked the «capitalists 》. The pamphlet contained a number of general accusations concerning economic collaboration and support by industrials for collaboration movements. The only tangible demand was the immediate arrest of: «All those who, by trading in the black market, ruined the health of the laboring classes. ${ }^{55}$ It thus seems that even militant organizations which wanted to politicize the repression issue had to adapt themselves to the specific way in which the economic collaboration was perceived by the population.

However, to say that the public opinion remained indifferent to the way the courts dealt with industrial collaboration would be too narrow a view. The reports by the national security service on the public opinion show that the population did demand measures against economic collaboration.

An accurate assessment of the extent of these demands requires detailed analysis. As in the case of the attacks against collaborators and of the social demands, stress was put on particular points. The first point, or criticism, concerned the equal treatment of economic collaborators and other types of collaborators. When talking about economic collaborators, the discussion did not centre on industrialists, but rather on the opposition between those who had enriched themselves and those who had not. Examples which are far too often quoted were black marketeers and traffickers (Limburg, Namur, West-Vlaanderen). As for the industrial collaboration, it was only the slow pace of justice which was criticized and the fact that some suspects were allowed to continue their activities (Liège, West-Vlaanderen). In some areas, it was the industrial collaboration which caused the most concern to people. This was the case in Liège, Mechelen (province of Antwerp) and Hainaut, where calls were made for stiffer sentences for the industrial collaborators and where the conviction of the carpentry firm De Coene of Kortrijk (West-Vlaanderen) which had supplied the German army with various goods, met with great approval. It was also in Hainaut that attempts were made to politicize industrial collaboration. At the beginning of June of 1945, a protest rally was organized against the amendment and weakening of article 115 of the Penal Code, which provided for the punishment of economic collaboration. This amendment also encountered resistance from the population in the Liège area, where people demanded the punishment of one of the large industrial collaborators. Here too, resistance organizations, first among which the Independence Front, attempted to politicize the issue. On 30 May 1945, the Independence Front organized a rally in Visé for which 400 people gathered. The central theme was the more stringent line on industrial collaboration. Interestingly

\footnotetext{
54 Report state security police Tongeren,19.III-25.III.1945, SOMA, Hoog Commissariaat, 1278.

55 «Tous ceux qui par le commerce noir ont ruiné la santé des classes laborieuses», Pamphlet CLS november 1944, SOMA, Hoog Commissariaat, 1654.
} 
enough, the colliery employers were not their main targets, which again indicates that the population did not generally reject the policies of the business community ${ }^{56}$. A similar picture emerges from the reports about the public opinion in Mechelen, the centre of the furniture industry. The population considered that the furniture manufacturers were not being dealt with harshly enough. Reports on rallies organized by resistance movements prove, however, that the protest was not predicated on patriotic motives in the main. The furniture manufacturers were attacked not so much for having worked for the Germans, but rather for paying low wages. It was this aspect in particular which was stressed by the speakers at the rally. The second bone of contention involved the president of the fish corporation, who was accused of having sold rotten fish to the population while providing the good products to the enemy ${ }^{57}$.

The sources for the reactions and views of the population regarding the economic collaboration issue reveal a shaded picture. The question remains as to the extent to which the policy of the Chief Military Prosecutor was influenced by the population's views and perceptions.

\section{THE CHIEF MILITARY PROSECUTOR AND PUBLIC OPINION}

There are various aspects involved in determining the influence of public opinion on the prosecution policy, but this should not be seen as a clear and mechanistic process with only two variables. The relationship is to be considered in the context of the process of restoration of the legitimacy of the state after the war. Seen from this angle the interaction between the prosecution policy and the societal environment had three aspects. The prosecution service tried to assess the reactions and sensibilities of the population and this was an element in the orientation of the policy of prosecution. This was considered to be a necessity in order to secure the legitimacy of the judiciary as part of the state. But Ganshof's strategy did not always or completely correspond to the government's policy. He used the reactions of the population against these political groups which advocated a very limited prosecution of economic collaboration.

The combining of the two positions of Chief Military Prosecutor and High Commissioner for the Security of the Territory was already a first indication that the reaction and sensitivities of public opinion were going to influence prosecution policy. It appears from the activities of the High Commissioner's Office that there was an intensive cooperation with the judicial departments. Reports from various police departments were communicated to the Chief Military Prosecutor's Office, which kept the military prosecutors informed of criticism of their action ${ }^{58}$. Reports by the national security service on the popular response to certain decisions were submitted to the president of the military court of appeal ${ }^{59}$.

\footnotetext{
56 Reports in SOMA, Hoog Commissariaat, 1300; 1303; 1307; 1311-1312; 1315-1317; 1323; 1326; 1327.

57 SOMA, Hoog Commissariaat, 1296.

SB Military security to the Chief Military Prosecutor, 7.VI.1945, SOMA, Hoog Commissariaat, 1293. The Chief Military Prosecutor to the Military Prosecutor in Mons, 13.XI.1944, ibidem, 117.1.

59 SOMA, Hoog Commissariaat, 1180.
} 
Ganshof believed that as Chief Military Prosecutor it was his task to make sure that the prosecution policy was legitimate in the eyes of the population. This becomes clear from a dispute he had with the Minister of the Interior in May 1945. In a circular, the latter had insisted that the prosecutors should lock up individuals who were known to be collaborators in order to forestall any hostile actions by the population against these people. Ganshof considered this circular a criticism of the work of the military prosecution departments and argued that the anger of the people was directed mainly at the released internees, for which responsibility lay with the consultative commissions, and not with the military prosecutors ${ }^{60}$. Thus, in Ganshof's mind, the success of the judiciary was to some extent tantamount to its acceptance by the population. This was stated unambiguously by the Chief Military Prosecutor in his address in 1946, in which he defended his prosecution policy. Ganshof remarked that the way collaboration was dealt with was a matter of great interest to the population, who expected severe punishment. The repression had to be finished quickly and should not be fundamentally different from that which public opinion deemed just. If not, there would have been a real risk of people taking matters into their own hands: «They [the prosecution departments] knew that unrest, violence, summary executions, popular retribution could be avoided only insofar as the justice system inspired peoples' confidence and was capable of carrying out its assigned task. ${ }^{61}$ The concern to avoid 'mob justice' also formed the background to the amendment of the procedure in which Ganshof, in his capacity as Chief Military Prosecutor and High Commissioner, had participated: «We would have had to fear procedural complications and the repression of those violations which most deeply offend the national conscience would have been impaired or even thwarted.» ${ }^{62}$ The actions by the judiciary had to be directed: «at punishing without hesitation those actions which were the most offensive to consciences. ${ }^{63}$ This also explains why criticism was levelled at the prosecution of petty collaborators: «The apparently petty offender is, in his own setting, in his own locality or region, an important source of reaction and pernanent ill feeling which only the courts can appease. $1{ }^{64}$

However, this does not imply that the Chief Military Prosecutor's policy was entirely determined by public opinion. On a number of points, it went against the views that were prevalent among the population. May it suffice to mention that, from the start, he gave instructions not to prosecute small economic collaborators and voluntary workers ${ }^{65}$. When assessing the influence of public opinion, a distinction has to be made between the direct and indirect impact.

60 Ganshof to the Minister of Justice, 10.V.1945 Rijksarchief Brugge, Archief A. Van Acker, 641.

61 alls [the prosecution departments] savaient que les troubles, les violences, les exécutions sommaires, la vengeance populaire, ne seraient évités que dans la mesure où la justice inspirait d'emblée confiance au pays et saurait faire face à sa mission", Ganshof Van der Meersch (1946, p. 5-6).

62 «Toutes les complications de procédure eussent été à redouter et la répression des infractions qui heurtent le plus profondément la conscience nationale eât été énervée, voire tenue en échec», Ganshof Van der Meersch (1946, p. 64).

63 «À sanctionner sans faiblesse les agissements qui heurtent le plus la conscience», ibidem, p. 80.

64 «Le coupable apparemment de peu d'envergure est dans son milieu, dans sa localité, dans sa région un foyer important de réactions et de ressentiment permanent, qu'apaisera seule l'action judiciaire», ibidem, p.80.

65 Réunion 5.X.1944, Auditoraat-generaal/Auditorat-général (Chief Military Prosecution Service), Documenten J. Gilissen. 
There was a direct impact on two specific points of the prosecution policy: the speed and the emphasis on results, on the one hand, and the great attention paid to all aspects of economic collaboration, on the other. Soon after the liberation, Ganshof wanted to bring a number of important economic collaborators before the courts and to punish them severely, which is why priority was given to four cases, in which there could be little discussion as to whether the supplies to the enemy were punishable at law since they were of a military nature ${ }^{66}$. In so doing, the Chief Military Prosecutor wanted to send a signal to the population that they should not get the impression that the courts acted leniently towards economic collaboration. For the same reason, it was to be avoided that higher appeal systematically resulted in a substantial reduction of sentences. In March 1946, the Chief Military Prosecutor received a message from the national security service to the effect that the population took exception to sentence reduction on appeal for an economic collaborator. This was considered a symptom of the unequal treatment of petty and major collaborators. Ganshof requested measures to speed up appeals, thus limiting the chance of a reduction of sentence ${ }^{67}$.

The second direct influence bears on the Chief Military Prosecutor's concern to make sure that economic collaboration would in fact be prosecuted instead of being allowed to go unpunished, a wish expressed by the business community and in some political quarters. Ganshof believed that the entire repression would be discredited if economic collaboration was ignored ${ }^{68}$. On several occasions, Ganshof's view led to conflicts with the government, which revolved around the amendment of article 115 of the Penal Code (April-May 1945), which was favoured by the government in order to temper a prosecution policy deemed too severe ${ }^{69}$.

This last point brings us to the indirect influence of public opinion on the prosecution policy. The indirect impact was more important than the direct one. Despite his efforts, the Chief Military Prosecutor did not succeed in implementing his original plan of prosecuting the major economic collaborators. Ganshof's policy was criticized not only by the business community, but also by politicians. This political opposition grew as time went on. Until the Spring of 1945, there was a «patriotic front ", which stretched from the Communist to part of the Socialist to part of the Liberal parties. The communists in particular made the prosecution of major economic collaboration a priority. In late 1945, it was only the Communist Party and part of the Socialist Party which still adhered to this view. The development of the socialists in particular is of importance here. The weakening of the tough stance was the result of pressure exerted by two factions. The first, which was that of Prime Minister Achille Van Acker, believed that it was not advisable to seek confrontation with the industrialists in the field of the repression at a time when a new social system was being set up ${ }^{70}$. The second faction, which favoured a moderate line against the industrial collaborators, consisted of union representatives in the Socialist Party.

66 Ganshof to the minister of Justice 27.XI.1944, ibidem.

67 Note from the Chief Military Prosecutor 28.III.1946, Archief documentatiedienst auditoraat-generaal/Archives service de documentation auditorat-général, G/2-5-20-208.

68 Ganshof to the Minister of Justice, 2.V.1945, Auditoraat-generaal/Auditorat-général, Documenten John Gilissen.

69 Luyten (1996, Ch. 3).

70 Huyse, Dhondt (1993, p. 237). 
They argued that industrialists should not be dealt with too harshly as there had been a consensus during the war between the employers and the workers to maintain production, even if this benefited the Germans, without however excessive profit making. This consensus may explain why none of the postwar reports of union managerial bodies makes any mention of the industrial collaboration issue. This tallies with the above-mentioned observations about the perception of industrial collaboration by the workers and public opinion. However, was not this 'consensus' an ideological construction used to serve the interests of the industrialists? Partly it was, but it did have some ties with reality. The sectors controlled by holdings, such as the mines, metallurgical and metal construction industries attempted to comply with the Galopin doctrine, named after Alexandre Galopin, governor of the Societé Générale, the main holding company. The doctrine was established by the leadership of the holdings and prescribed a code of conduct for industry in times of occupation. Although it implied that factories were allowed to work for the Germans, there were limits to the extent to which this could be done, and always with certain restrictions. Profit-making was never supposed to be a motive. This production policy was considered essential in order to ensure the provisioning of the country and to safeguard the workers against deportation to Germany. The policy of the Galopin committee had to be coupled with a social policy towards the workers ${ }^{71}$. This was not a policy of unbridled politically inspired collaboration; rather it was intended to enable the company to survive the war ${ }^{72}$. As for companies, like the steelworks Ougrée-Marihaye, which followed this policy, the courts did not find many incriminating facts to warrant instituting charges ${ }^{73}$. The second element which places the ideological character of the consensus argument into perspective is the fact that the working classes depended on companies for their survival ${ }^{14}$. To this end, companies had to have a minimum of economic activities, which would always to some extent benefit the enemy. It was precisely this which the Galopin doctrine allegedly had in mind. In light of these observations, it is hardly surprising that workers and the public opinion took a relatively mild view of industrial collaboration.

An argument a contrario for the consensus thesis is found among the industrialists who were prosecuted after the war. This often involved companies which had treated their workers badly. The following two examples illustrate this. The first case is that of a Limburg metal-construction company which had supplied the Germans with shaking conveyors. The manager was particularly hated because of his 'difficult personality' and the low wages he paid his workforce. Moreover, he was accused of having incited several workers to go and work in Germany ${ }^{75}$.

The East Flemish shipbuilder B., who was sentenced to eight years imprisonment, could not exactly be accused of having followed a progressive social policy either. He extended the working hours, introduced Sunday work, and restricted

71 Van den Wijngaert (1990).

72 For this distinction: Beltran, Frank, Rousso (1994, p. 385).

73 Hofmans (1992).

74 Fridenson, Robert (1992, p. 147).

75 Uiteenzetting der zaak Krijgsraad Tongeren/Exposé de l'affaire Conseil de guerre, Tongres, 5.X.1945, Griffie Krijgshof Brussel Strafdossier L./Greffe Cour Militaire Bruxelles, Dossier pénal L. 
sabotage, while there was a strict disciplinary regime in the yard with a great deal of supervision. However, the major bone of contention was the introduction of the Bedaux-system, which was particularly hated by the workers ${ }^{76}$.

After the war, these entrepreneurs could not count on any «solidarity » on the part of their workers, which made prosecution easier. Those industrialists who followed the recommendations of the Galopin committee had succeeded in creating a kind of goodwill among their workforce. This resulted in the population at large not judging their behaviour too harshly. It raised the threshold for legal action, especially when it was faced with a growing political opposition which looked askance at the actions of the Chief Military Prosecutor against large-scale industrial collaboration and which made the consensus argument a core issue in its defence of economic collaborators.

\section{CONCLUSIONS}

In this article, we have examined the relationship between the policy of the Chief Military Prosecutor and the population's reactions to the repression of economic collaboration. This form of crime affected various aspects of society. The central question was whether actions by the judiciary were influenced by the social surroundings, and if so, in what way.

The Chief Military Prosecutor, who was also the High Commissioner for the Security of the Territory, believed that the punishment of economic collaboration had to correspond to some extent with the views of the population. This is why he made a priority of quickly and severely punishing this type of collaboration. This was considered to be crucial for the restoration of the authority and the legitimacy of the state after the liberation.

Public opinion and the workers demanded a severe punishment of economic collaboration but gave a specific definition to this concept. The population's resentment was directed mainly at those economic collaborators who were closest to their dayto-day lives and/or played a direct role in their survival strategies. Shopkeepers, tradesman, traffickers and black marketeers were targeted more than industrial collaborators, who were criticized only if they had had too many business dealings with the enemy or had treated their workers badly.

On the whole, industrialists who had subscribed to the Galopin doctrine were not targeted. This may be explained by the restrictive nature of their economic activity, which was necessary to keep the workers in the country and to ensure their survival.

This specific perception by public opinion of economic collaboration had direct and indirect effects on the judiciary. Economic collaboration could not be excluded from prosecution as a matter of course. The indirect consequence was that the Chief Military Prosecutor's Office could not carry the prosecution policy to the extreme as the societal base was not large enough to counter growing political opposition.

More detailed investigation is required in order to place the judicial action in as wide a context as possible and to view it as a social phenomenon. It is the entire legal

76 Deskundigeverslag/Rapport d'expertise A. Celis, 2.VII.1947, p. 190 ff., Griffie Krijgshof Brussel Strafdossier B./Greffe Cour Militaire Bruxelles, Dossier pénal B. The Bedaux system, named after the French engineer Charles Bedaux, was designed to increase labour productivity. Its basis was time measurement of each act of an individual worker in the global production process. 
proceedings, rather than just the prosecution, which need to be examined. The few international efforts in this field have proven the usefulness of this approach ${ }^{77}$.

Dirk Luyten

Vrije Universiteit Brussel

Faculteit der Rechtsgeleerdheid

Pleinlaan, 2

B-1050 Brussel

\section{REFERENCES}

Beltran, A., Frank, R., Rousso, H. (eds.), La vie des entreprises sous l'occupation. Une enquête à l'échelle locale, Paris, 1994.

Cassart, G., L'internement des suspects et des étrangers. Arrêté-loi du $12 . X .1918$ et son application en 1944, Bruxelles, 1944.

Fridenson, P., Robert, J.L., Les ouvriers dans la France de la Seconde Guerre mondiale. Un bilan, Le mouvement social, 1992, 158, p. 117-148.

Ganshof Van der Meersch, W.J., Réflexions sur la répression des crimes contre la sûreté extérieure de l'État Belge, Bruxelles, 1946.

Gérard-Libois, J., Gotovitch, J., Léopold III. De l'an 40 à l'effacement. Bruxelles, 1991.

Gilissen, J., Étude statistique de la répression de l'incivisme, Revue de droit pénal et de criminologie, 1951, p. 513-628.

Gilissen, J., La répression de la collaboration avec l'ennemi 1944-1951, undated (unpublished manuscript).

Gotovitch, J., Du rouge au tricolore. Les communistes belges de 1939 à 1944. Un aspect de l'histoire de la Résistance en Belgique, Bruxelles, 1992.

Hofmans, G., Het probleem van de ekonomische kollaboratie. De houding van de groep de Launoit tijdens de Tweede Wereldoorlog, Bijdragen van het Navorsings- en Studiecentrum voor de Geschiedenis van de Tweede Wereldoorlog, 1992, 15, p. 5-52.

Huyse, L., Dhondt, S., La répression des collaborations. Un passé toujours présent. Bruxelles, 1993.

Huyse, L., Hoflack, K. (ed.), De democratie heruitgevonden. Oud en nieuw in politiek België 1944-1950, Leuven, 1995.

Jacquemyns, G., La société belge sous l'occupation allemande, 1940-1944. Mode de vie, comportement moral et social, Bruxelles, 1950, 3 vols.

Jacquemyns, G., Quelques attitudes et réactions des travailleurs belges sous l'occupation allemande (1940-1944), Revue d'histoire de la Deuxième Guerre mondiale, 1958, VIII, 31, p. 24-31.

Laborie, P., Histoire politique et histoire des representations mentales, in Peschanski, D., Pollak, M., Rousso, H. (eds.), Histoire, politique et sciences sociales, Bruxelles, 1991, p. 155-169.

Luyten, D., Burgers boven elke verdenking? De vervolging van de economische collaboratie in België na de Tweede Wereldoorlog, Brussel, 1996.

Martinage, R., Les collaborateurs devant la cour d'assises du Nord après la très Grande Guerre, Revue du Nord, 1995, LXXVII, p. 95-115.

77 Rochebrune, Hazera (1995). 
Pauwels, W., De bevrijdingsdagen van 1944. Honderd dagen tussen anarchie en burgeroorlog, Antwerpen, 1994.

Rapport sur l'activité du Haut Commissariat à la Sécurité de l'État, 29.VIII.1943-1.XI.1945 (date unknown).

Rochebrune, R. de, Hazera, J. C., Les patrons sous l'Occupation, Paris, 1995.

'T Hart, A. C., Openbaar Ministerie en rechtshandhaving, Arnhem, 1994.

Van den Wijngaert, M., Nood breekt wet. Economische collaboratie of accommodatie. Het beleid van Alexandre Galopin gouverneur van de Société Générale tijdens de Duitse bezetting (1940-1944), Tielt, 1990.

Veraghtert, K., Het economisch leven in België 1918-1940 in Nieuwe Algemene Geschiedenis der Nederlanden, Haarlem, 1979, vol. XIV, p. 53-101. 